\title{
LANGUAGE EDUCATION IN NIGERIA: CONTEMPORARY ISSUES AND WAY FORWARD
}

\author{
Matthew O. Iwuchukwu \\ Department of Foreign Languages and Literary Studies \\ University of Nigeria, Nsukka \\ Email: matthew.iwuchukwu@unn.edu.ng; moiwuchukwu@yahoo.com \\ DOI: 10.47760/cognizance.2021.v01i02.001
}

\begin{abstract}
Nigeria is a highly multiethnic and multilingual African country that speaks over 500 indigenous languages and two official languages, English and French, some of which are taught and learned at the primary, secondary and tertiary levels of education. This descriptive study has attempted to discuss the state of language education and related issues in the education sector, involving the mother tongue, English, French and Arabic languages. The paper elucidates a few omissions in the National Policy on Education (NPE) and other factors that militate against effective implementation of the language curriculum such as negative perception, inadequate teaching staff and instructional resources, falling students' enrolment and performance, year abroad challenges, lack of funds and controversies generated by debates on a good lingua franca, etc. Based on the findings and their implications for achieving the objectives of the $N P E$, some recommendations have also been made for a way forward, for example, the need to review the existing NPE and language curriculum, implement trilingual education, compulsory and free basic education, provide sufficient funds, constitute internal quality assurance committees, carry out research and publish standard textbooks for pupils and students, and create umbrella associations of language teachers at the primary, secondary and tertiary levels of education.
\end{abstract}

Keywords: Nigeria, language education, policy, curriculum, mother tongue, official languages, issues, way forward.

\section{INTRODUCTION}

I feel highly delighted and honoured to take part in today's event as lead paper presenter.

The role of language in human, national and international development cannot be overemphasized, especially in this era of globalization and information and communication technology of the $21^{\text {st }}$ century. Defined in the Oxford Advanced Learner's Dictionary as "the system of communication in speech and writing that is used by people of a particular country", 


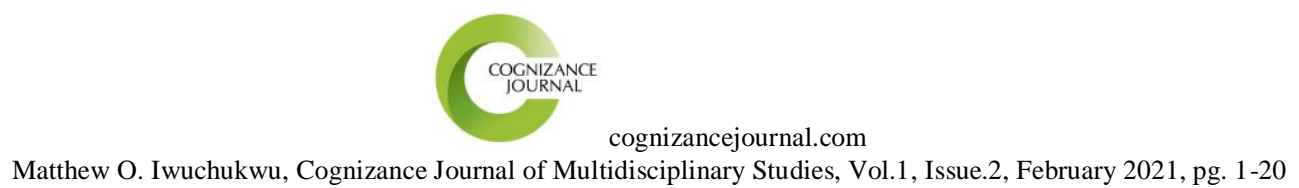

language is viewed as the people's property which enables speakers to communicate with one another and with others at both the local and international levels. In other words, language plays a vital communicative role in the development of every country, especially in the educational, scientific, cultural, social and economic sectors. Thus, the theme of this conference, "Language Education and Contemporary Issues in Nigeria", underscores the importance and relevance of language education in the country. In fact, language is one of the most significant tools for sustainable development in the world, especially in the developing African countries such as Nigeria. With over 500 indigenous languages, English, French and Arabic spoken within her borders, Nigeria is a highly multiethnic and multilingual country in Africa involving the following indigenous languages : Hausa, Igbo, Yoruba, Fulani, Ijaw, Uhrobo, Igala, Tiv, Efik, Ibibio, Edo, Nupe, Gwari, Igala, Idoma and hundreds of others (Iwuchukwu 2006). It is expected that the study and use of these languages by Nigerian speakers will promote the much desired Nigeria’s cultural diversity and unity.

On this note, permit me to start by defining the term language education. What is the relationship between language and education? Education depends on human language for its very existence and development. This unique role of language in the education sector is reciprocal in the sense that language, like other academic disciplines, also needs education for its existence and development. Thus, on the one hand, language education refers to the use of language as a medium for teaching and learning various subjects and on the other hand, being primarily a branch of applied linguistics, it involves teaching and learning of a language with a view to improving the listening, speaking, reading and writing (LSRW) skills of pupils/students. This paper discusses the state of language education in Nigeria as well as some contemporary issues 


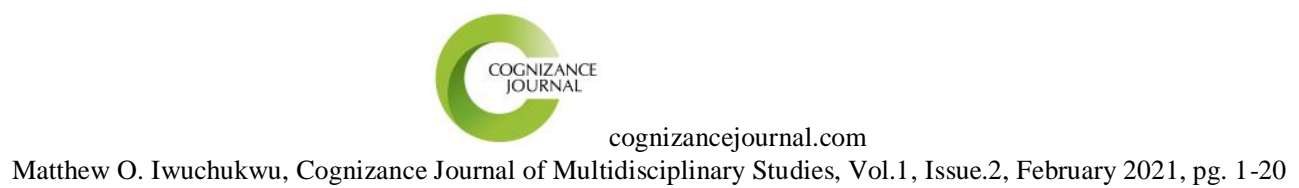

surrounding the education sector at the primary, secondary and tertiary levels, and it also offers some recommendations for a way forward. The study is divided into six parts as follows: languages in the National Policy on Education (NPE), mother tongue or indigenous language education, second or official language education, language in tertiary education, other language education related issues, and recommendations.

\section{LANGUAGES IN THE NATIONAL POLICY ON EDUCATION (NPE)}

Prior to the attainment of political independence in Nigeria in1960, both the nature and main thrust of language education in the formal school system were determined mostly by the Christian missionaries who encouraged the teaching and learning of English and indigenous languages in our schools. (Fafunwa 1974:92). Thus, from 1960 -present, the Federal Government has published six versions of the National Policy on Education (1977, reprinted 1981, 1995, 1998, 2004, 2007 and 2013, reprinted 2014) and each of them recognizes the multilingual nature of the country as well as the importance of languages in various fields of human endeavour. For instance, building on the provisions of 1999 Constitution (Section 55), the $4^{\text {th }}$ Edition of the NPE (2004) reinforces the various language communication needs of the country through the prescription of indigenous languages as well as English, French and Arabic in both the primary and secondary school curricula. Specifically, at the primary education level, the $N P E$ makes provisions for the teaching and learning of the mother tongue or "language of the immediate community" (L1) and English/French/Arabic language (L2) for the first three or four years of basic education.

Thereafter, English is listed as a compulsory subject (L2) while French and Arabic are language options (L3) for the last three years in primary school (primary 4-6) and at the level of 


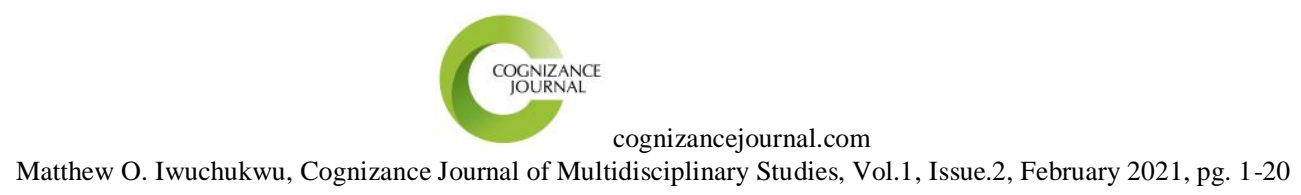

junior secondary school (JSS 1-3). At the level of senior secondary education, the compulsory status of English language is upheld while French and Arabic become "non-vocational electives" (Sections 1- 3). However, in the $6^{\text {th }}$ and current edition of the NPE (reprinted 2014), French, Arabic and "any Nigerian language that has curriculum" are in the core curriculum of senior secondary education (Section 38.2), the clause "non-vocational electives" having been expunged from the policy document. Can this action on the part of policy-makers be translated as an upgrade of the status of French and Arabic in the language provisions of this edition? What is the real status of mother tongue or indigenous language education in terms of policy formulation and implementation?

\section{MOTHER TONGUE OR INDIGENOUS LANGUAGE EDUCATION}

The 2005 Ethnologic Data listed a total of 521 languages for Nigeria out of which 510 are living languages, 2 are second languages without mother tongue speakers, and 9 are extinct (Cited by Dada 2012: 57). In other words, 508 out of a total of 510 living languages are indigenous languages with mother tongue speakers in Nigeria. It is pertinent to emphasize the prescription of indigenous languages in the basic education curriculum, three of them having been accorded a federal status as national languages, that is, Hausa, Igbo and Yoruba as contained in both the Constitution of the Federal Republic of Nigeria and National Policy on Education.

However, what we consider crucial in this paper is the issue of incomplete formulation and non-implementation of the existing policy on the child's mother tongue. For instance, on the issue of "Early Child Care Development and Education" (ECCDE), there is no provision for languages in pre-primary education "given to children aged 5 prior to their entering primary 


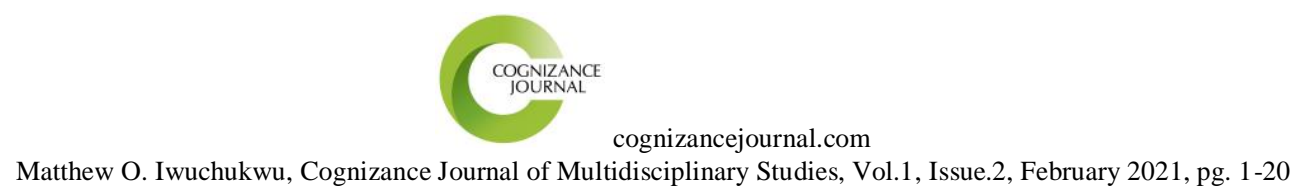

school" (2014, Section 2.17). At this stage, the teaching and learning of the child's mother tongue (L1) should be encouraged to ensure a smooth transition from pre-primary to primary education, given that the mother tongue or language of the immediate community is a compulsory subject during the first three years of primary education.

Interestingly, the three major Nigerian languages (Hausa, Igbo and Yoruba) occupy a favoured position in the NPE (2004) as follows:

Government appreciates the importance of language as a means of promoting social interaction and national cohesion; and preserving culture. Thus every child shall learn the language of the immediate environment. Furthermore, in the interest of National unity it is expedient that every child shall be required to learn one of the three Nigerian languages: Hausa, Igbo and Yoruba (Section 1.10a).

Unfortunately, the above provision appears to be a declaration of language policy without implementation although this policy has existed for more than fifteen years. Some researchers in the language education sector like Bamgbose (2013) and Ashofor et al (2016) decried the provisions for mother tongue education without implementation due to the use of English language as the medium of instruction in many primary schools across Nigeria, especially during the first three or four years of basic education. Ashofor et al also rightly pointed out that "there are teachers that are teaching pre-primary/primary school pupils in Hausa, Igbo or Yoruba dominated areas in English language". There is also the issue of using English language (L2) in teaching the mother tongue or language of the immediate community (L1). In view of the foregoing, the teaching and learning of the three major Nigerian languages - Hausa, Igbo and Yoruba - and others should be strengthened in line with the language provisions of the NPE, Nigeria being a highly multiethnic, multilingual and multicultural country. This explains why Section 55 of the 1999 Constitution recognizes English, Hausa, Igbo and Yoruba as languages in 
Matthew O. Iwuchukwu, Cognizance Journal of Multidisciplinary Studies, Vol.1, Issue.2, February 2021, pg. 1-20

which the official business of the National Assembly can be conducted, English language being the official language and others major Nigerian languages.

\section{SECOND OR OFFICIAL LANGUAGE EDUCATION}

As a follow-up to the declaration of General Sani Abacha's regime in 1998, the $4^{\text {th }}$ edition of the National Policy on Education (2004) also promotes the status of French as Nigeria's second official language after English, in recognition of the importance and relevance of French language in the West African sub-region where Nigeria has played and will continue to play a major leadership role. Thus, "for smooth interaction with our neighbours, it is desirable for every Nigerian to speak French. Accordingly, French shall be the second official language in Nigeria and it shall be compulsory in primary and Junior Secondary School" (Section 1.10b). This justifies the prescription of French language as a core course subject in the primary and junior secondary school curricula (pp.5, 15 and 19). However, this language provision also appears to be another policy declaration without implementation. As a second official language, the teaching and learning of French should normally start at the level of early child education or the first three or four years of basic education and along with the teaching and learning of the indigenous language (L1) and English (L2), in order to curb the risk of language interference in the process of language skills acquisition.

It is heartwarming to note that the Government and several millions of Nigerian speakers recognize the role of English and French in national and international development, both languages being viewed as global languages as well as the official languages of many intraAfrican and international organizations such as the Economic Community of West African States (ECOWAS), Economic Community of West African States Cease-Fire Monitoring Group 
cognizancejournal.com

Matthew O. Iwuchukwu, Cognizance Journal of Multidisciplinary Studies, Vol.1, Issue.2, February 2021, pg. 1-20

(ECOMOG), River Niger Basin Authority, Lake Chad Basin Commission, African Union (AU), African Development Bank (ADB) and New Partnership for African Development (NEPAD). Others are the United Nations Educational, Scientific and Cultural Organization (UNESCO), United Nations Children's Emergency Fund (UNICEF), World Health Organization (WHO), Organization of Oil Exporting Countries (OPEC), Association of African Universities (AAU), Association of French-speaking Universities (Francophonie) of which the University of Ibadan and University of Lagos are currently Associate members, etc.

Furthermore, in the light of international "trilingualism" propounded by the UNESCO, (Opara 2007), there is also need to implement the language provisions of the NPE which include the mother tongue, English as the official language and French, a "neighbour" language and the official language of 11 neighbouring African countries: Benin Republic, Burkina Faso, Cameroon, Chad, Côte d'Ivoire, Guinea, Mali, Mauritania, Senegal, Niger and Togo.

Some Nigerian speakers, however, refuse to recognize or accept the status of English and French as Nigeria's official languages. They rather view them as "foreign" or "colonial" languages that should be replaced with a suitable mother tongue as official language. Contributing to the debate, Agbedo et al (2012) argue in favour of an undisclosed mother tongue in "Mother Tongue Education as Agency of Decolonisation: Implications for National Development in Nigeria". On the other hand, Abdulhafee Mei (2014) posits as follows: "Arabic is the only Nigerian indigenous language, being the native language of Shua Arabs of the present day Bornu State, with international appeal to argue for its adoption"; but the question that arises from this suggestion is as follows: What is the real status of Arabic in Nigeria today: mother tongue or foreign language? 
The controversies generated by the debate over Nigeria's lingua franca might have affected the revised language provisions of the National Policy on Education published after 2004. Specifically, the $5^{\text {th }}$ and $6^{\text {th }}$ editions of this policy document no longer contain the provisions for the official language, but English and French still occupy a favoured position in the curriculum in the sense that both languages are core subjects at both the senior primary and junior secondary school levels.

In Nigeria today, the status of English language is however much better than that of French, the latter being the language of instruction and taught in most primary, secondary and tertiary schools across the country. As a second official language, French should also enjoy all the rights and privileges of every official language such as compulsory teaching and learning at all levels of education, use in government offices, churches, National Assembly, schools, colleges and universities.

\section{LANGUAGES IN TERTIARY EDUCATION}

What is the status mother tongue, English, French and other of languages in tertiary education, that is, teaching and learning of languages in universities, language institutes or centres, colleges of education and polytechnics? Although tertiary education appears in the NPE, there is no provision for languages or language curriculum at this level of education. However, the National Universities Commission (NUC) provides undergraduate curriculum in indigenous languages, English, French, German, Portuguese, Russian and Italian in the Benchmark for Minimum Academic Standard (BMAS). The NUC encourages the teaching and learning of these languages in all federal, state and private universities across the country. In 


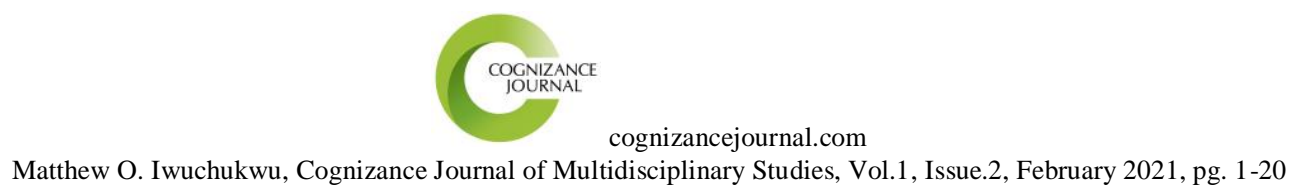

addition, this education commission promotes the teaching of some languages in three special language institutes or centres as follows:

1. National Institute for Nigerian Languages (NINLAN), Aba, established in 1993 under the regulation of the National Universities Commission (NUC), charged with the responsibility of promoting the study and use of Nigerian languages as well as research, documentation and coordination of studies in Nigerian languages.

(The Sun of 26/04/16: https://www.sonnewsonline.com)

2. Arabic Language Village (ALV), Ngala, established for the purpose of teaching and learning of Arabic language.

3. The Nigeria French Language Village (NFLV), Badagry, established in 1991, an acculturation and immersion centre for students of French.

Permit me to address further the teaching and learning of French as a second official language in the Nigerian university system. French language is taught in the Department of Foreign Languages in some universities like the University of Nigeria, Nsukka, University of Benin, University of Uyo, Obafemi Awolowo University, Ile-Ife, etc. The teaching of this language is done in the Department of Modern European Languages at the University of Lagos, University of Ibadan, Nnamdi Azikiwe University, Awka, etc. However, in the University of Jos, Delta State University, Abraka, and Ebonyi State University, Abakaliki, the undergraduate curriculum in French is housed in the Department of Languages and Linguistics. As a second official language, Nigeria has to continue to invest in the teaching of French at all levels of education, notably in universities, in order to promote and defend her strategic interests in the West African sub-region and beyond. On this note, French deserves to be created and sustained as an autonomous department in the entire Nigerian university system. Interestingly, the Department of French already exists in some universities as follows: Ahmadu Bello University, 


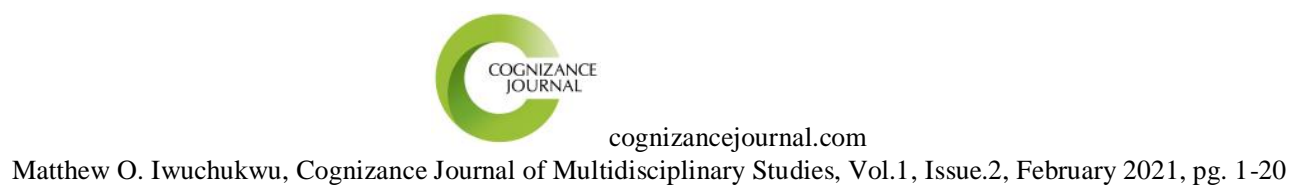

Zaria, Bayero University, Kano, University of Ilorin and Federal University, Lafia, Many Nigerian universities also offer M.A. and Ph.D. programmes in French, in addition to their B.A. single honours or B.A.(Ed) in French, and some of their qualified graduates are recruited to serve as French teachers at the primary, secondary and tertiary levels of education.

There is also need to make French a General Studies (GS) course, like English, as practiced in some universities like the University of Ibadan, Federal University of Technology, Owerri, Michael Okpara Federal University of Agriculture, Umudike, Anambra State University, Uli, Abia State University, Uturu, Delta State University, Abraka, etc. The University of Ibadan runs a collaborative GS programme in French, jointly sponsored and run by the University of Ibadan and Centre for French Teaching and Documentation (CFTD)/Alliance française in Ibadan. Furthermore, some polytechnics like the Federal Polytechnic, Oko, and Delta State Polytechnic, Ogwashi Uku, also offer similar GS course in French to their students. Although this practice in French without policy is commendable, there is still "need for policy formulation and implementation" in this regard, as Iwuchukwu (2004: 289-302) rightly pointed out in his earlier publication.

Faculties of Education and Colleges of Education across Nigeria also make significant contributions to the development of language education in the country. Specifically, they get deeply involved in the training and retraining of language teachers in the primary, secondary and tertiary education sector, that is, teachers of indigenous languages, English, French and Arabic. However, some researchers lament the poor performance of some language students on account of their preference for certain subjects combined to the detriment of others. For instance, according to Offorma (2012: 146), "the students focus more on the subjects combined with 
Matthew O. Iwuchukwu, Cognizance Journal of Multidisciplinary Studies, Vol.1, Issue.2, February 2021, pg. 1-20

French and neglect French especially at the Colleges of Education”. Moreover, the researcher "observed that the proficiency attained in French language by the teachers is very low and that invariably affects the learners' achievement in French". At the university level, it has indeed been observed that B.A. single honours students of French generally perform better than their B.A./Education in French counterparts. In other words, among other challenges, students' subject combinations in language education as well as inadequate performance on the part of teachers impact negatively on students-teachers' achievement in French.

It appears that this phenomenon also manifests itself in the teaching and learning of other languages like English. Idowu (2015: www.researchgate.net) also elucidates this anomaly in the teaching of English language in the tertiary education system:

Over the years, several researches on English language education [...] reveal a high level of deficiency and incompetence in the English used by graduate and undergraduate students of English in the various tertiary institutions in Africa. This is evident in the high level of dissatisfaction of lecturers with the use of English language by students in Nigerian tertiary institutions for both written and spoken expressions, which are plagued with slangs and pidgin forms.

According to many researchers, the issue of use of slangs and pidgin forms in English is mainly due to the abusive use of the social media on the part of students in secondary and postsecondary schools, for example, the problem of interference of social media slangs in spoken and written English like the use of "n isokay" and " $u$ shud kw dat" for the correct expressions "and it is okay" and "you should know that" respectively. This phenomenon is comparable to the issue of interference of pidgin English in French language, for example, "Garri too sweet" for "J'arrive tout de suite", etc. 


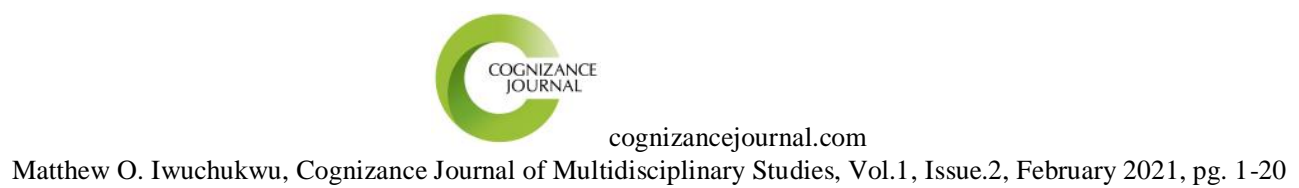

\section{LANGUAGE EDUCATION RELATED ISSUES}

This paper has also identified for further discussion other language Education related issues that hamper effective implementation of the language policy and curriculum as follows:

\section{Non-implementation of some Provisions of the National Policy on Education}

It has been observed that some provisions of the National Policy on Education have not been implemented or well implemented over the years, notably the provisions for "compulsory, free, universal and qualitative" basic education (Section 2.12).

\section{Psychological issues}

Negative perception of language education on the part of some Nigerian speakers, especially students and their sponsors, because they generally prefer "juicy courses" in medicine, pharmacy, engineering, law and others.

\section{Falling Students' Enrolment and Performance}

Students' enrolment in languages is currently falling, especially in indigenous languages, French and Arabic. It has also been observed that the performance of many language education students fall short of expectations, especially in the language components of their degree or Nigerian Certificate in Education (NCE) programmes, due to a number of factors such as nonimplementation or partial implementation of policy, negative perception of language education, lack of funds and instructional resources, etc. Adequate measures should, therefore, be put in place to remedy the situation since most of the students will eventually graduate to become teachers of languages at the primary, secondary and tertiary levels of education. 


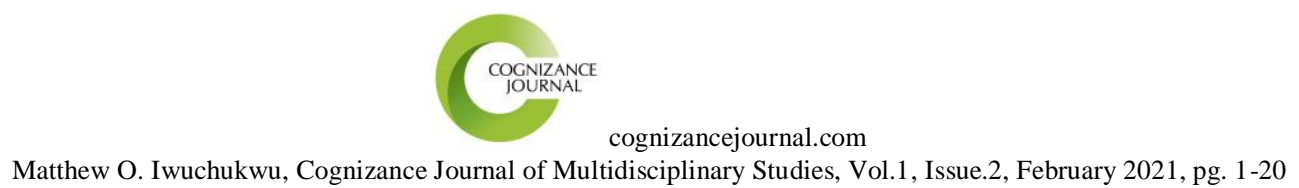

\section{Inadequate Teaching Staff}

Researchers decry the inadequacy of teaching staff in number and quality. Many private and public schools at the primary, secondary and tertiary levels lack qualified, competent and dedicated teachers capable of responding to the demands of students and innovative teaching.

\section{Inadequate instructional resources}

Language demands a variety of experimental instructional resources and activities such as language laboratory, books, televisions, videos, pictorials, internet, debates, excursions, etc. The provision of these materials, especially the modern gadgets, is inadequate and this situation militates against effective implementation of language curriculum.

\section{Lack of funds}

Most schools and departments at all levels of education also lack funds needed for effective implementation of language policy and curriculum, that is, funds needed to cater for the welfare of staff and students as well as for the provision of instructional resources as indicated above. According to The Punch newspaper, budgetary provision for education in the annual budget represents $7.04 \%$ in 2018 and $7.05 \%$ in 2019 , both having "fallen below the 15 per cent to 20 per cent minimum recommended for developing countries by the United Nations Educational, Scientific and Cultural Organization” (https://punching.com).

\section{Year Abroad Challenges}

Due to lack of funds at the level of tertiary education, some parents/sponsors and their wards studying foreign languages like French, German and Russian cannot afford to cater for the year abroad programme outside Nigeria. 
Matthew O. Iwuchukwu, Cognizance Journal of Multidisciplinary Studies, Vol.1, Issue.2, February 2021, pg. 1-20

\section{Language Curriculum Issues}

It has been observed that some Nigerian languages do not have curriculum and that the existing language curriculum has not been adequately tailored to meet the demands of the labour market.

\section{Lack of Internal Quality Assurance Mechanism}

In addition, it has been reported that most schools/departments do not have any functional internal quality assurance mechanism.

\section{Non-Existence of Umbrella Association of Language Teachers}

There is no umbrella association of language teachers representing all levels of education for each of the languages in the curriculum: indigenous languages, English, French and Arabic. For instance, Afolabi (2010 : 332-334) observed that in some countries like Ghana, Republic of Benin, France and USA, there is only one national association of French teachers which cater for French teachers at the primary, secondary and tertiary education levels, and that this association is also an active member of the international umbrella association based in France: $L a$ Fédération Internationale des Professeurs de Français (FIPF). He noted that in Nigeria, an umbrella association of French teachers had existed between the 1960s and 1980s.

\section{Youth unemployment}

Nigeria is currently facing peculiar challenges of unemployment among youths, including some graduates and NCE holders in language education.

\section{RECOMMENDATIONS FOR A WAY FORWARD}

Based the above results, the following are some recommendations for a way forward: 


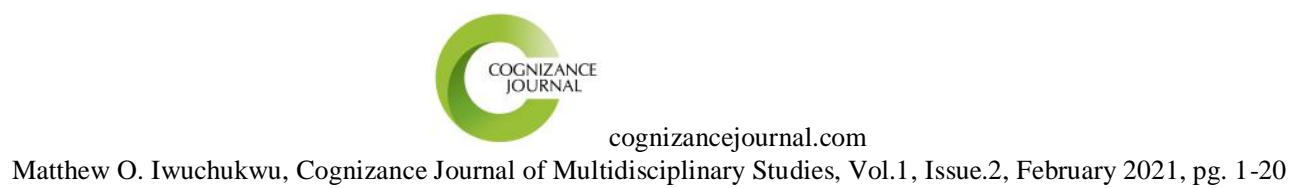

\section{Review the Existing National Policy on Education}

There is need to review the existing National Policy on Education and make adequate provisions for trilingual education to ensure the teaching of the mother tongue, English and French at all levels of education. The federal and state governments should also put in place all necessary measures to ensure effective implementation of the policy on languages. It is expected that, if formulated and implemented, this practice will go a long way in curbing the risk of language interference in the process of language skills acquisition.

\section{Review the Language Curriculum}

Such a review of the national policy on education will also necessitate a review of the language curriculum in line with the revised minimum standard of three tertiary education commissions as follows: the National Universities Commission (NUC), National Commission for Colleges of Education (NCCE) and National Polytechnic Commission (NPC). Their updated minimum standard documents should reflect the status of French as a second official language and as a General Studies (GS) course in tertiary institutions.

\section{Provide Sufficient Funds}

The federal and state governments, school management and private sector should provide sufficient funds to ensure effective implementation of the language policy and optimal performance on the part of staff and students. This will also enable management to create and sustain an enabling school environment and cater for the welfare of all staff and students. Thus, in line with the minimum provision recommended for developing countries by UNESCO, there is need to increase the budgetary allocation to education in Nigeria from $7.05 \%$ in 2019 to $15 \%-$ $20 \%$ in subsequent years. On this note, it will be recalled that the education sector was given 


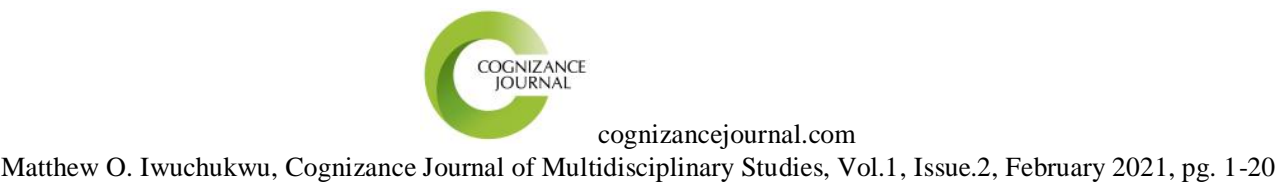

$17.5 \%$ in 1997, and this budgetary allocation to education adhered to the said recommendations on education funding by state.

\section{Implement Compulsory and Free Basic Education}

The provisions for compulsory and free basic education should be implemented as contained in the NPE (2014): "Basic education, to be provided by Government, shall be compulsory, free, universal and qualitative. It comprises: 1-year of Pre-Primary, 6 years of Primary [and] 3 years of Junior Secondary Education" (Section 2.12).

\section{Constitute Internal Quality Assurance Committees}

Internal quality assurance committees should also be constituted or reconstituted at all levels of education in the country.

\section{Get Involved in Research and Publish Standard Textbooks and Journal Articles}

Teachers at all levels of education should be encouraged to get involved in productive research and publish standard textbooks and journal articles to be used as resource materials in schools, colleges, polytechnics and universities across Nigeria. They should also participate in staff development programmes and capacity building activities such as conferences, training workshops and seminars, etc.

\section{Create Umbrella Associations of Language Teachers}

There is need to recreate and sustain the umbrella association of French teachers in Nigeria and create new ones for each of the other languages in the curriculum - mother tongue, English and Arabic. The primary objective of the said association will be to cater for language teachers and promote the teaching of languages at the primary, secondary and tertiary levels of education. 
Matthew O. Iwuchukwu, Cognizance Journal of Multidisciplinary Studies, Vol.1, Issue.2, February 2021, pg. 1-20

Year Abroad Programme in French

Year Abroad in the Nigeria French Language Village, Badagry, should be made compulsory for all students of French in tertiary institutions.

\section{Encourage Stakeholders’ Participation}

All stakeholders should be encouraged to participate actively in the process of policy implementation with a view to moving language education in Nigeria to the next level: federal and state governments, schools/universities, language immersion centres, teachers and teachers' associations, students and students' associations, parents and sponsors, etc.

\section{CONCLUSION}

This study discusses language education and a number of contemporary issues militating against effective implementation of the language curriculum in Nigeria, specifically in respect of the teaching and learning of the mother tongue, English, French and Arabic languages at the primary, secondary and tertiary levels of education. The paper elucidates some language education related issues like the challenges of teaching the following languages and recommendations for a way forward: indigenous language education, second or official language education, English and French, and foreign languages in tertiary education. A few omissions in the National Policy on Education (NPE) and other issues are highlighted, for example, negative perception of language education, inadequate teaching staff and instructional resources, falling students' enrolment and performance, year abroad challenges, lack of funds and internal quality assurance mechanism, controversies generated by debates on a good lingua franca, etc. 


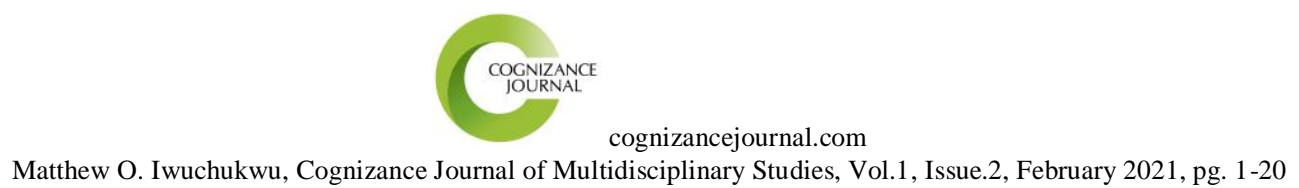

Based on the results of the study and their implications for achieving the objectives of the NPE, the study also makes some recommendations for a way forward such as the need to take the following actions: review the existing national policy on education, implement trilingual education, compulsory and free basic education, provide sufficient funds, constitute internal quality assurance committees, get involved in research and publish standard textbooks for pupils and students, and create umbrella associations of language teachers at the primary, secondary and tertiary levels of education.

Finally, while thanking the organizers of the conference for giving me the opportunity to serve as lead paper presenter, I wish you all very successful and fruitful deliberations at this great event.

\section{NOTE}

1. Revised version of the lead paper presented by the author of this article at the $7^{\text {th }}$ National Conference of the School of Languages, held at the Federal College of Education, Eha-Amufu, Enugu State, Nigeria, on $16^{\text {th }}$ July, 2019.

\section{REFERENCES}

[1]. Abdulhafee Mei (2014). "The Nigerian National Language Question: Arabic as a Viable Option". https://www.researchgate.net.

[2]. Afolabi, Segun (2010), «Promouvoir le français au Nigeria à travers une approche communicative », Kaduna State University Journal of French (KASUJOF), Maiden Edition, Vol.1, No. 1, pp. 329-340.

[3]. Agbedo, Chris Uchenna et al (2012). "Mother Tongue Education as Agency of Decolonisation: Implications for National Development in Nigeria", Developing Country Studies, Vol 2, No.11, pp. 170-181. www.liste.org.

[4]. Aire, Victor O. (2007). "UFTAN at 10". Keynote Address Delivered at the University of Benin, Benin-City. 
[5]. Ashofor, A.H. et al (2016). "The Importance of Indigenous Languages in Teaching and Learning: Implications for ECCE and PED Students", CAJES: Capital Journal of Education Studies, Vol. 4, No. 1.

[6]. Bamgbose, Ayo (2013). "Language Provisions Of Nigeria's National Policy On Education: Declaration Without Implementation", NILAS-A Journal of The National Institute for Nigerian Languages, Vol 3, No. 1, Fafunwa Foundation Internet Journal of Education.

[7]. Dada, Samuel A. (2012). "Language Policies and Planning in Nigeria : Issues and Perspectives", in D.D. Kuupole et al (Eds.) Cross-Currents in Language, Literature and Translation, Festchrift for Prof J.P.A. Ukoyen, Porto-Novo: Editions SONOU d'Afrique, pp. 56-79.

[8]. Danladi, Shaibu Sunday (2013). "Language Policy: Nigeria and the role of English Language in the $21^{\text {st }}$ Century", European Scientific Journal, Vol. 9, No. 17, pp. 1-21: https:/eujournal.org

[9]. Fafunwa, A.B. (1974). History of Education in Nigeria, London: George Allen \& Unwin.

[10].Federal Republic of Nigeria (1999), Constitution of the Federal Republic of Nigeria. Lagos: Federal Government Press.

[11].Federal Republic of Nigeria (2004, 2014), National Policy on Education. Lagos: Federal Government Press.

[12].Idowu, Olubunmi (2015). "Sociolinguistics and English Language Education in Nigerian Higher Institutions", Paper Presented at the 3rd School of Education and Humanities Conference on the Future of Higher Education in Africa held at Babcock University: https://www.researchgate.net

[13].Iwuchukwu, Matthew O. (2006). «Le français en milieu multilingue africain: le cas du Nigeria ». Journal of Oriental and African Studies, Vol. 15 , pp. 223-238.

[14]. (2004). "French as Nigeria's Second Official Language: Need for Policy Formulation and Implementation", Nsukka Journal of the Humanities, No. 14, pp. 289-302.

[15].Lieberson, S. (1982). "Forces Affecting Language Spread: Some Basic Propositions", In Cooper, R.L. (Ed.) Language Spread. Bloomington: Indiana University Press, pp. 37-62.

[16].Offorma, Grace C. (2012). "French Language Education in Nigeria" https://www.researchgate.net/publication/280554230.

[17].Opara, C.C. (2007). "Achieving International "Trilingualism" through the Nigerian Language Policy: Myth or Reality", International Journal of Educational Studies (IJEST), Vol. 3, No. 1, pp. 104-121. 


\section{COGNIZANCE
JOURNAL}

cognizancejournal.com

Matthew O. Iwuchukwu, Cognizance Journal of Multidisciplinary Studies, Vol.1, Issue.2, February 2021, pg. 1-20

[18].The Punch. "2019 Budget: Education gets N620.5bn against UNESCO's Advice", https://punching.com > 2019-budget-education. Published January 4, 2019.

[19].The Sun of 26/04/16. On National Institute for Nigerian Languages (NINLAN). https://www.sunnewsonline.com. 